\title{
Belbin team roles in a start-up team
}

\author{
Richard Bednár ${ }^{1, *}$ and Ivana Ljudvigová ${ }^{1}$ \\ ${ }^{1}$ University of Economics in Bratislava, Faculty of business management, Dolnozemská cesta 1, 852 \\ 35 Bratislava, Slovakia
}

\begin{abstract}
Leadership in start-ups has its specific features, which are connected to a high uncertainty, moving of current boundaries, outstanding adaptability and perseverance of the founder. The main goal of this research paper was to identify the role of founders in successful start-ups. The purpose of this research is to determine whether there are certain common characteristics of successful entrepreneurs- start-up founders. In our analysis, we used the questionnaire- Belbin Full Individual Report. This questionnaire analyses and compares self-evaluation of an examined individual with 360-degree analysis of four members of his team. As a successful start-up we defined a company which fulfilled all of the following conditions: creates a unique scalable product/service, exists on the market 4 to 6 years and is achieving revenues in the amount of the third quartile (Q3) in its industry. To make the analysis comparable, analysed figures are only men. In our research we analysed nine founders and CEOs of start-ups base on a 360-degree evaluation- self-evaluation and evaluation of four members of the team. To view cumulative results, we have used the function boxplot.
\end{abstract}

\section{Introduction}

Establishment and development of start-ups is inevitably associated with leadership, because applied leadership has a decisive impact on the success or failure of a start-up [1]. For a start-up to work like a team it is necessary to unite in order to achieve a common goal and that is precisely the sense of leadership. Where teamwork is important, leadership is also important and vice versa. Team work and leadership are necessary for the success of any start-up [2]. On the contrary the absence of leadership can have a range of negative impacts for start-up business. Start-up without a leader, who creates and communicates a vision, inspires and coaches and interferes with processes and business activities, when it is necessary, operates on the market aimlessly [1]. Nevertheless, there is relatively little empiric research done, that would deal with the topic of leadership in start-ups. Many of the finding in this area are still based on theoretical inquiry. The main goal of this contribution therefore is to examine the role of a leader in start-up teams.

\section{Theoretical basis of leadership in start-ups}

\footnotetext{
* Corresponding author: richard.bednar@euba.sk
} 
The uncertainty, or the uncertain future represents the next important factor when characterizing the concept of start-up. Blank and Dorf [3] argue, that "start-up goes from failure to failure in order to learn from each failure and find out what works in the process of finding repeating business model with high growth". The uncertainty inside of a novice business is caused by short business tradition, lacking experience and low level of developing routines and processes. The uncertainty is however also linked to external environment in which start-up operates and is given by in particular specific conditions of the environment, complexity and dynamics on the market. The third crucial parameter in the defining of a start-up is the criteria of growth. The value of a start-up lies exclusively in its future growth potential. Aspects of growth are stressed in Graham's definition [4], who refers to start-ups as "an enterprise, which is created for rapid growth".

The personality of a founder, his business history, engagement, impression, confidence and affinity, which are for investors and partners decisive criteria when it comes to obtaining necessary investment resources. It is confirmed by Kets DeVries and Miller [5], according to which individual characteristics and behaviour of leaders influences the development and long-term sustainability of start-ups As well as according to Hambrick and Mason [6] start-ups are often seen as a reflection of its management. The demonstration of perseverance and resilience, reliability and honesty [7] are the most important characteristics of a novice entrepreneur, which is appreciated by the potential investor. Butler [8] indicates, that business leaders are successful in the environment of uncertainty, they are motivated by the risk, they are characterised by an extraordinary ability to convince and keen curiosity towards external environment. Similarly, Bussgang [9] ranks the ability to deal with uncertainty and pushing the boundaries of traditional business as the most important characteristics of leaders in start-ups. Many empiric studies have shown a positive relationship between the leaders behaviour and different indicators of the performance of start-upists [10, 11, 12].

Most investors, when deciding on investing into a particular business idea look for competent, highly biased and credible management team with relevant experience in the relevant field. The quality of a start-up team is according to Timmons and Spinelli [7] judged based on these criteria: experience, motivation, perseverance, creativity, responsibility, courage, adaptability, tolerance of risk and uncertainty. It is confirmed by Blank and Dorf [3], according to whom a start-up team has to be used to change, chaos, learning from mistakes, risk-taking and unstable situations without instructions on the solution, must be curious, searching, creative and eager in search of repeatable and scalable business model.

One of the experts, who are intensely devoted to the issue of team and team roles is Meredith Belbin [13, 14]. the object of his interest was to find out the reasons, why some teams achieve great results and others face failure. In 1970 he, with a group of experts from Henley Management College, decided to conduct a study, which would bring answers to this question. He intensely watched the behaviour of managers using a series of different psych-evaluation for the duration of ten years. On the basis of the results of the evaluations was the sample of managers divided into seven categories. Subsequently, these managers were divided into teams, in which they carried out different managerial tasks. During the observation of task-solving, certain patterns of behaviour of this research sample were identified. On the basis of these patterns the researchers identified the basic team roles. Initial research team defined eight team roles, but over the time added a ninth role. These nine team roles were divided into three groups based on their orientation - roles oriented in dealing with people (coordinator, team worker and spotter of sources), roles oriented in action (rectifier, producer, finisher) and roles oriented in thinking (Specialist, Plant, Monitor evaluator). A short description of team roles according to their strengths and weaknesses is illustrated in Table 1 [14]. 
Table 1. Typology of team roles according to Belbin.

\begin{tabular}{|c|c|c|}
\hline & Benefits & The negatives \\
\hline Shaper (SH) & $\begin{array}{l}\text { Call for performance, is dynamic, performs well } \\
\text { under pressure. Is enterprising and daring when it } \\
\text { comes to overcoming obstacles. }\end{array}$ & $\begin{array}{l}\text { Is inclined to provoke. Offends the } \\
\text { feelings of others. }\end{array}$ \\
\hline $\begin{array}{l}\text { Co-ordinator } \\
\text { (CO) }\end{array}$ & $\begin{array}{l}\text { It is a matured and self-confident, is able to } \\
\text { recognize talent. Clarifies objectives. Effectively } \\
\text { delegates. }\end{array}$ & $\begin{array}{l}\mathrm{He} \text { may seem manipulative. } \mathrm{He} \\
\text { exonerates his share of the work. }\end{array}$ \\
\hline Plant (PL) & $\begin{array}{l}\text { Creative, has imagination, free-minded. Generates } \\
\text { ideas and solves difficult problems. }\end{array}$ & $\begin{array}{l}\text { Ignores details. He is fully preoccupied } \\
\text { with his own thoughts to the detriment of } \\
\text { effective communication. }\end{array}$ \\
\hline $\begin{array}{l}\text { Teamworker } \\
\text { (TW) }\end{array}$ & $\begin{array}{l}\text { Works, is responsive, and diplomatic. Listens and } \\
\text { to prevent disagreements between people. }\end{array}$ & $\begin{array}{l}\text { Is indecisive in critical situations. Avoids } \\
\text { sharp conflicts. }\end{array}$ \\
\hline $\begin{array}{l}\text { Completer } \\
\text { finisher }(C F)\end{array}$ & $\begin{array}{l}\text { Is attentive, conscientious, diligent. Searches for } \\
\text { errors on the way to perfection. }\end{array}$ & $\begin{array}{l}\text { Is inclined to excessive worrying. } \\
\text { Reluctant to delegate. }\end{array}$ \\
\hline $\begin{array}{l}\text { Resource } \\
\text { investigator } \\
\text { (RI) }\end{array}$ & $\begin{array}{l}\text { Is sociable, enthusiastic and communicative. } \\
\text { Detects opportunities and develops contacts. }\end{array}$ & $\begin{array}{l}\text { Is excessively optimistic. May lose } \\
\text { interest after the initial enthusiasm. }\end{array}$ \\
\hline Specialist (SP) & $\begin{array}{l}\text { Is focused on one single thing, proactive and } \\
\text { focused on his own area. Provides rare knowledge } \\
\text { and skills. }\end{array}$ & $\begin{array}{l}\text { Contributes only in the demarcated area. } \\
\text { Deals with professional matters. }\end{array}$ \\
\hline $\begin{array}{l}\text { Implementer } \\
\text { (IMP) }\end{array}$ & $\begin{array}{l}\text { Is practical, reliable, powerful. Transforms ideas } \\
\text { into actions and organises work that needs to be } \\
\text { done. }\end{array}$ & $\begin{array}{l}\text { Is a little inflexible. Slowly responds to } \\
\text { new opportunities. }\end{array}$ \\
\hline $\begin{array}{l}\text { Monitor } \\
\text { evaluator } \\
\text { (ME) }\end{array}$ & $\begin{array}{l}\mathrm{He} \text { is factual, strategist and smart. He sees all } \\
\text { possibilities. He has a precise judgement. }\end{array}$ & $\begin{array}{l}\text { He may lack the drive and ability to } \\
\text { inspire others. May be over-critical. }\end{array}$ \\
\hline
\end{tabular}

\section{The objectives and Methods}

The result of Belbin's study was the finding that most successful were those teams that were composed of a variety of people (different team roles). It is necessary to mention that some members of the team are able to uphold multiple roles at the same time. Businesses, world advice organisations and the leaders themselves constantly use this typology as a guide to create a team. So far however the Belbin typology of team roles has not been applied to start-ups and their founders. The main aim of the implemented research team was to identify the role/roles of the founders in start-up teams and based on the that examine the importance of leaders in start-ups. The purpose of this mentioned research is to determine whether there as certain common characteristics of successful entrepreneurs (start-up founders). A prerequisite for the fulfilment of the objective is to verify the following hypothesis:

1. Every leader upholds several team roles, of which as least four proceed the boarder of occurrence by 50 percent.

2. The combination of team roles in leaders of successful start-ups will be the same.

3. At least in one team role it will be the same or similar tendency (high or low representation).

The output of the conducted survey may serve as a role model for people who are about to establish their own start-up and do not know what team role they should as the founder hold and similarly for leaders of already existing star-ups who face the problems caused by unclear roles and failure of teamwork. The results of the survey may also be a tool for investors, business angels and institutions supporting a developing start-up (whether they 
are private or state) when deciding which criteria, they should consider when assessing a new potential start-up business.

The main research method was certified survey questionnaire Belbin. Belbin analysis creates a personalized report on the individual behaviour. The starting point is the individual report generated directly by Belbin, who identified which combination of the nine is represented in the studied personality, in what proportions, defines the strengths and weaknesses of the personality and contains a proposal to self-improvement personality, in order to achieve higher efficiency.

In our analysis, we used the questionnaire- Belbin Full Individual Report. This questionnaire analyses and compares self-evaluation of an examined individual with 360degree analysis of four members of his team. We have defined a successful start-up as a business that fulfils all of the following conditions:

- creates a unique, scalable product/service

- is on the market 4 to 6 years,

- achieved sales in the amount of the third quartile (Q3) in its industry.

To make the analysis comparable, analysed figures are only men. In our research we analysed nine founders and CEOs of start-ups based on a 360-degree evaluation - selfevaluation and evaluation of four members of the team. To view the cumulative results, we used the function of boxplot which is rather descriptive but also allows the assess the variability and symmetry of the data, further serves to detect outliers and extreme observations. The latter consists of a rectangle (i.e. a box) and whiskers (i.e. an antenna). The rectangle takes about half the data set, its lower part is determined by the lower quartile, the upper edge defining the upper quartile. The height of the box is therefore given by so called Interquartile Range which we obtain from the relation IQR $=x 0,25-x 0,75$ where $\mathrm{x} 0,25$ indicates the lower quartile and $\mathrm{x} 0,75$ the upper quartile. The box is divided into two parts of the median, which represents the skew. We obtain the lower part in the relation $\mathrm{x} 0,25-1,5 \cdot \mathrm{IQR}$, the upper then similarly $0,75+1,5 \cdot \mathrm{IQR}$. The values, that do not belong into the interval bounded by walls are considered suspicious and are shown as a ring.

\section{Results and discussion}

In the results of the research we show brief characteristic of the examined start-ups and their founders including the resulting table of the representants of team roles of each leader. Analysis of each founder is completed by brief pointing his strengths and weaknesses and from that resulting space for improvement in the role of the team leader:

Table 2. Business model and results of Belbin analysis.

\begin{tabular}{|l|l|l|l|l|l|l|l|l|l|l|}
\hline & Company Description & SH & CO & PL & TW & CF & RI & SP & IMP & ME \\
\hline $\begin{array}{l}\text { Powerogy } \\
\text { CEO } \\
\text { Dušan }\end{array}$ & $\begin{array}{l}\text { Online shop of of improved } \\
\text { products such as organic } \\
\text { chocolate, coffee, special coconut } \\
\text { oil, almond butter and others. }\end{array}$ & $78 \%$ & $6 \%$ & $100 \%$ & $0 \%$ & $0 \%$ & $98 \%$ & $84 \%$ & $11 \%$ & $0 \%$ \\
\hline $\begin{array}{l}\text { Zelená pošta } \\
\text { CEO } \\
\text { Adrián }\end{array}$ & $\begin{array}{l}\text { Sending and receiving mail via the } \\
\text { online system. }\end{array}$ & $48 \%$ & $57 \%$ & $28 \%$ & $44 \%$ & $67 \%$ & $21 \%$ & $19 \%$ & $58 \%$ & $68 \%$ \\
\hline $\begin{array}{l}\text { Octago } \\
\text { CEO } \\
\text { Dušan }\end{array}$ & $\begin{array}{l}\text { Building and selling customers } \\
\text { customized fields for street } \\
\text { workout. }\end{array}$ & $38 \%$ & $24 \%$ & $20 \%$ & $24 \%$ & $55 \%$ & $98 \%$ & $38 \%$ & $68 \%$ & $92 \%$ \\
\hline
\end{tabular}




\begin{tabular}{|c|c|c|c|c|c|c|c|c|c|c|}
\hline $\begin{array}{l}\text { Venzeo } \\
\text { CEO - Jozef }\end{array}$ & $\begin{array}{l}\text { Helping companies document } \\
\text { manual activities and problems in } \\
\text { the field. }\end{array}$ & $78 \%$ & $30 \%$ & $77 \%$ & $24 \%$ & $60 \%$ & $66 \%$ & $50 \%$ & $39 \%$ & $56 \%$ \\
\hline $\begin{array}{l}\text { sli.do } \\
\text { CEO - Peter }\end{array}$ & $\begin{array}{l}\text { Online platform for conferences: } \\
\text { Q\&A sessions, live polls, live } \\
\text { quizzes, brainstorm ideas }\end{array}$ & $50 \%$ & $22 \%$ & $76 \%$ & $60 \%$ & $26 \%$ & $84 \%$ & $97 \%$ & $20 \%$ & $49 \%$ \\
\hline $\begin{array}{l}\text { MeetNlearn } \\
\text { CEO - Juraj }\end{array}$ & $\begin{array}{l}\text { Online platform for mediation of } \\
\text { tutoring between the tutors and the } \\
\text { students. }\end{array}$ & $3 \%$ & $2 \%$ & $94 \%$ & $25 \%$ & $60 \%$ & $33 \%$ & $92 \%$ & $10 \%$ & $93 \%$ \\
\hline $\begin{array}{l}\text { StartitUp } \\
\text { CEO - } \\
\text { Marek }\end{array}$ & $\begin{array}{l}\text { An information web which would } \\
\text { connect all start-up enthusiasts. } \\
\text { Startitup Group has a portfolio of } \\
\text { eight websites. }\end{array}$ & $72 \%$ & $76 \%$ & $98 \%$ & $20 \%$ & $36 \%$ & $88 \%$ & $0 \%$ & $0 \%$ & $19 \%$ \\
\hline $\begin{array}{l}\text { Zaraguza } \\
\text { CEO - } \\
\text { Michal }\end{array}$ & $\begin{array}{l}\text { Ranked by Facebook as one of the } \\
\text { TOP } 10 \text { most creative agencies in } \\
\text { the world. }\end{array}$ & $90 \%$ & $71 \%$ & $100 \%$ & $25 \%$ & $36 \%$ & $67 \%$ & $0 \%$ & $0 \%$ & $0 \%$ \\
\hline $\begin{array}{l}\text { Aktivizer } \\
\text { CEO - Ján }\end{array}$ & $\begin{array}{l}\text { Application which offers various } \\
\text { sports activities to choose from in } \\
\text { one's leisure-time. }\end{array}$ & $82 \%$ & $92 \%$ & $62 \%$ & $50 \%$ & $14 \%$ & $66 \%$ & $20 \%$ & $30 \%$ & $38 \%$ \\
\hline
\end{tabular}

Based on comparing the individual types of roles demonstrated by founders of the examined start-ups (Figure 1) we can observe that each of the analysed leaders displays a different combination of roles carried out in his team (hypotheses no. 1). What this also means is that there is no role or a combination of roles which would be sure to guarantee a start-upist's success (hypotheses no. 2).

Figure 1. Boxplot.

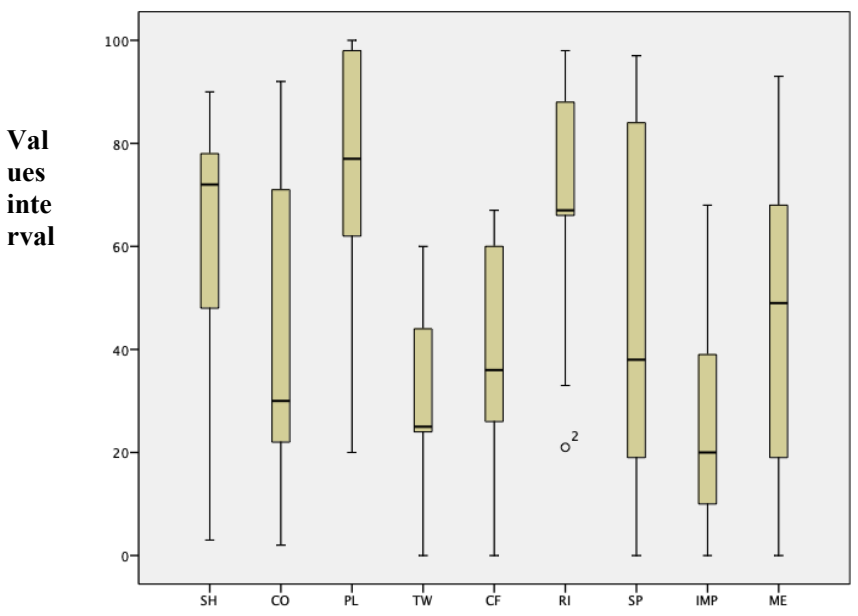

Belbin team roles

Regards to two particular types ui ivies, uie ivunuers iendency to demonstrate them is rather low (Table 10). We're speaking of the role of a Teamworker (an average value of 30.22) and an Implementer (an average value of 26.22). Based on the general characteristics of a Teamworker - this person is perceptive, diplomatic and easy to cooperate with. He listens, pays attention and avoids disagreements; he builds relationships and diverts conflicts. On the other hand, there is his indecisiveness in crucial situations 
(Belbin, 2010). Start-up leaders are in their nature very competitive, which also shows in a lowered ability to cooperate with others. Start-up founders tend to pay more attention to goals and tasks rather than to interpersonal relationships at their workplace, which may be due to their age, considering these businesses are often pretty young. However, a leader's lack of ability to cooperate and solve conflicts may have a negative impact on his future. Research proves that start-ups lead by teams of several people are in the long-run more successful than those lead by an individual. Team (collective) leadership, in start-ups especially, undeniably dominates at the expense of vertical leadership (based on a formal leader). Moreover, unresolved conflicts between the members of start-up teams are one of the most common reasons why people leave them, which eventually causes these start-up businesses to perish.

The team role of an Implementer was least demonstrated by the founders of examined start-ups (26.22). According to our theoretical starting point, an Implementer is someone practical, reliable and efficient. He transforms ideas into action and arranges any task there is to be done. He implements solutions which his team has agreed on. He's disciplined, dependable, conservative in his habits, yet always able to act and take practical steps. His downside lies in his rigidity, best shown in his slow reactions to new possibilities (Belbin, 2010). It is indeed for this reason that the role of an implementer is much less demonstrated by the examined start-ups' founders. A start-up business is characterized by its bumpy ride to success, full of unsuccessful projects and having to adjust its business model to the needs of its customers. Flexibility, quick reactions to changes and proactivity are therefore the typical traits of a successful start-up-team leader.

The samples we've decided to analyse point out one team role which is relatively highly demonstrated by all leaders (hypotheses no. 3). It was the role of a Shaper, a person who's able to deal with difficult problems and comes up with solutions. His personality could be defined as individualistic, creative, innovative and unorthodox. His best quality is imagination, whereas his weaknesses encompass his negligence towards being subsidiary and a preoccupation with his own thoughts at the expense of effective communication [14]. After its realization, the research project discovered that founders of successful start-ups are sensible, open, energetic and creative. Based on these characteristics, leaders create visions for their companies, as it turns out that innovativeness, curiosity and creativity are indeed some of the most important characteristics leaders of successful start-ups can possess. At the same time, it is important for the long-term future of a start-up business to encourage and develop creativity of one's co-workers.

Table 10. A comparison individual team roles demonstrated by founders of examined start-ups.

\begin{tabular}{|l|l|l|l|l|}
\hline & Minimum & Maximum & Mean & $\begin{array}{l}\text { Std. } \\
\text { Deviation }\end{array}$ \\
\hline Shaper & 3 & 90 & 59.89 & 27.733 \\
\hline Co-ordinator & 2 & 92 & 42.22 & 32.568 \\
\hline Plant & 20 & 100 & 72.78 & 30.626 \\
\hline Teamworker & 0 & 60 & 30.22 & 18.089 \\
\hline Completer finisher & 0 & 67 & 39.33 & 23.06 \\
\hline Resource investigator & 21 & 98 & 69.00 & 27.134 \\
\hline Specialist & 0 & 97 & 44.44 & 38.497 \\
\hline Implementer & 0 & 68 & 26.22 & 24.601 \\
\hline Monitor evaluator & 0 & 93 & 46.11 & 35.254 \\
\hline
\end{tabular}

The research project has shown that leaders of start-ups differ from leaders of traditional businesses. Several examinations concerning team roles, which are executed in standard teams inside regular organizations, have indicated that the "ideal" leadership roles are those of a coordinator, source seeker and a team operative $[15,16,17]$. Furthermore, the 
team roles of a coordinator and a team operator have reached a below-average presence in the examined start-up leaders, meaning that whatever helps a leader to manage his team in a traditional business is not the same thing as that which stands behind a start-upist's success.

There are many well educated and skilful people on the Slovak market, but the question is whether they are the right people to work on a start-up. Not everyone is inclined to dynamism, which is a typical feature of innovative businesses. Working on a start-up requires a creative, yet demanding activity without any actual limits. There is no precise prescription of work activities for individual positions which means that especially in their first years of existence, innovative businesses have to engage everyone in everything. The results of aforementioned research project prove this to be true as they show that leaders of successful start-ups tend toward several different team roles in various combinations. A leader's current choice of a team role mainly depends on the situation in which he finds himself. It turns out important for the success of a startup that he knows how to use the strengths of each team role to the best of his ability. Here, the analysis carried out according to Belbin's questionnaire could prove to be a suitable and explicit additional tool, used by institutions supporting the development of start-ups to evaluate these businesses and their founders. The biggest perk of this tool lies in its simplicity, not being time demanding and in the credibility of its conclusions, confirmed by decades of experience with businesses and consulting firms all over the world.

\section{Conslusion}

Every entrepreneur wants to enter the market with an innovative idea, put it into practice in the form of a start-up, impress potential customers and become successful. While it is true that an idea is truly an important stepping stone to launching a start-up, identifying the right people for such innovative business is one of the hardest tasks. Here, Belbin's analysis, identifying the team role displayed by each given start-up team's founder, becomes a great aid at determining the suitability of given leadership traits for leading and managing a start-up. Being put into practice and examining nine successful start-ups and their founders, the research project has shown that those who take the lead in start-up businesses display various team roles. It turns out to be very important, in start-up businesses especially, for a leader to demonstrate multiple team roles in order to strengthen his versatility. In regards to start-ups, the most important roles seem to be those of a Plant, source seeker and a director as opposed to the roles of a coordinator and a team operator, crucial when leading teams in traditional business.

\section{Acknowledgement}

The paper is a part of solving the task of VEGA no. no. 1/0631/19. Title: Metamorphoses of startups on the road to business success.

\section{References}

1. Zäch, S., Baldegger, U. (2017). Leadership in start-ups. International Small Business Journal: Researching Entrepreneurship, 2017, 35, pp. 157-177. 
2. Cogliser, C. C., Brigham, K. H. 2004. The intersection of leadership and entrepreneurship: Mutual lessons to be learned. The Leadership Quarterly, 15 (6), pp. 771-799.

3. Blank, S., Dorf, B. 2012. The start-up owner's manual. The step-by-step guide for building a great company. K\&S Ranch Publishing Division. ISBN-10: 09849993032.

4. Graham, P. 2013. Retrieved from http://www.forbes.com/sites/natalierobehmed/2013/12/16/what-is-a-startup/.

5. Kets de Vries, M. R., Miller, D. 1986. Personality, culture, and organization. Academy of Management Review, 11(2), pp. 266-279.

6. Hambrick, D. C., Mason, P. A. 1984. Upper echelons: The organization as a reflection of its top managers. Academy of Management Review, 9(2), pp. 193-206.

7. Timmons, J. A., Spinelli, S. 2008. New Venture Creation: Entrepreneurship for the 21st Century. 8. ed. London: McGraw-Hill. ISBN 978-0-0733-8155-8.

8. Butler, T. 2017. Hiring an entrepreneurial leader. Harvard Business Review, 2 (March-April 2017), pp. 85-93.

9. Bussgang, J. 2017. Are you suited for a start-up? Harvard Business Review, 6 (November-December 2017), pp. 150-153.

10. Gooty, J., Gavin, M., Johnson, P. D., Frazier, M.L, \& Snow, D. B. 2009. In the eyes of the beholder: Transformational leadership, positive psychological capital, and performance. Journal of Leadership \& Organizational Studies, 15 (4), pp. 353-367.

11. Gumuslouglu, L., Ilsev, A. 2007. Transformational leadership, creativity, and organizational innovation. Journal of Business Research, 62 (4), pp. 461-473.

12. Wang, H., Tsui A. \& Xin, K. 2011. CEO leadership behaviors, organizational performance, and employees' attitudes. The Leadership Quarterly, 22 (1), pp. 92-105.

13. Belbin, R. M. 1993. Team Roles at Work. Butterworth-Heinemann, Oxford.

14. Belbin, R. M. 2010. Management Teams: Why They Succeed or Fail. 3rd ed., Butterworth- Heinemann, Oxford.

15. Fisher, S. G., Hunter, T. A., Macrosson, W. D. K. 2000. The distribution of Belbin team roles among UK managers, Personnel Review, Vol. 29 No. 2, pp. 124-140.

16. Dulewicz, V., Higgs, M. J. 2003. Design of a new instrument to assess leadership dimensions and styles, Henley Working Paper Series No. HWP 0311, Henley Management College, Henley-on-Thames.

17. Batenburg, R., Walbeek, W. Van, Maur, W. 2013. Belbin role diversity and team performance: is there a relationship? Journal of Management Development, 2013, 32(8), pp. 901-913. 